\title{
Ethnic Cultural Interaction of the Population of the North Caucasus Territories
}

\author{
Tatyana Barsukova ${ }^{1}$, Andrey Lezhebokov ${ }^{2}$, Valentina Ivashova ${ }^{3, *}$, Roza Chvalun ${ }^{4}$, Oksana Gavrilova ${ }^{5}$. \\ ${ }^{1}$ Doctor of Sociology, Professor, Professor of the Department of Sociology, North-Caucasian Federal University \\ ${ }^{2}$ Doctor of Sociology, Professor, Professor of the Department of Sociology, North-Caucasian Federal University \\ ${ }^{3}$ Candidate of Sociology, Associate Professor, Associate Professor of the Project Management Department, FSBEI HE Stavropol \\ State Agrarian University \\ ${ }^{4}$ Candidate of Philology, Senior Lecturer of Foreign Languages Department, FSBEI HE Stavropol State Agrarian University \\ ${ }^{5}$ Candidate of Philology, Associate Professor, Associate Professor of Foreign Languages Department, FSBEI HE Stavropol State \\ Agrarian University
}

\begin{abstract}
The article presents the results of a sociological study devoted to the analysis of social practices of the population of several territories of the North Caucasus in the current sphere of ethnic cultural interactions. The study was conducted in 2019 by questionnaire survey in Stavropol Krai, KarachayCherkessia, and Ingushetia. In a number of issues, comparative data from the 2013 survey are involved, which allows us to see trends in the development of ethnic cultural interactions among the population of the strategically important territory of Southern Russia. The study found that an increase in the specific gravity of non-titular nationalities for Stavropol Krai, on the one hand, causes greater interpenetration of cultures, their mutual enrichment, on the other hand, an increase in the intensity of interaction between different national groups leads to the need for closer attention to the development of balanced national policies in the region. According to the survey participants, an increase in information about the history and culture of peoples living in the territory of the region will become a stabilizing factor in international relations.
\end{abstract}

\section{Introduction}

The harmonization of interethnic relations, the prevention of extremism, interethnic intolerance and hostility are, especially in the current conditions of significant international geopolitical shifts, one of the key tasks in ensuring the national security of Russia as a whole and its regions.

The constant attention and improvement of ethnic cultural interactions in the multinational region is of particular relevance in connection with the increase in the processes of mobilization of the ethnic factor in political manipulations and destabilization of territories by a number of foreign political forces.

The unity and mutual respect of different peoples, the harmony of different cultures, languages, and traditions are the source of strength of our country. Goodneighborly interethnic and interfaith relations in the south of Russia remain one of the critical indicators of the wellbeing of the region, which is subject to monitoring in order to maintain friendly relations between all ethnic groups and faiths. It is important to ensure a situation where ethnic cultural and confessional differences are not factors of destabilization of the socio-political climate of the region.

\section{Literature review}

The relevance of the study of the substantive characteristics of the social practices of the population in the field of ethnic cultural interactions, interethnic relations is confirmed by the interest of scientists in this issue in various regions of the world.

Author of the article "Ethnic Inequality, Cultural Distance, and Social Integration: Evidence from a NativeSettler Conflict in the Philippines" McDoom O.S. emphasizes that for the ethnically diverse region under study, issues of relations between indigenous people and migrants are relevant. A detailed analysis of the barriers to integration created by ethnic cultural differences was carried out on the basis of studying the evolution of interethnic marriages in society, as one of the productive strategies of social integration [1]. Among the important conclusions of the researcher, consonant with the opinion of a number of scholars, a decrease in the cultural distance between the indigenous population and immigrants ensures the socio-economic well-being of the territory $[2,3,4,5,6,7,8]$.

Ethnic cultural interaction as a social process initially has great conflict potential. Researcher Barwiński M. in his article "Geographical, Historical and Political Conditions of Ongoing and Potential Ethnic Conflicts in Central and Eastern Europe" presents his opinion on the possibilities of mobilizing the ethnic factor in regional

\footnotetext{
*Corresponding author: vivashov@mail.ru
} 
geopolitical competition [9]. The author emphasizes that such approach by politicians poses a real threat to stability and peace in Central and Eastern Europe [10, 11, $12,13,14,15,16]$.

The role of education as one of the most important social institutions that ensure the formation of values and norms of ethnic cultural interaction in modern society is emphasized in a study by scientists Geerlings J., Thijs J., Verkuyten M. "Preaching and Practicing Multicultural Education: Predicting Students' Outgroup Attitudes from Perceived Teacher Norms and Perceived Teacher Classmate Relations" [17]. The results showed that students of both the ethnic majority and ethnic minority expressed a more positive attitude towards ethnic groups when they felt the approval of the teacher. We find such conclusions in the studies of the authors Toksonalieva R.M., Musurmanova G.S., Astashova N.A., Bondyreva S.K., Koriakina A.A., Tretyakova T.V., and others [18, 19, 20, 21].

Thus a review of publications by contemporary authors confirms the interest in studying the social practices of ethnic cultural interaction between the population of various regions and social communities.

The purpose of the research work is to study the nature and orientation of ethnic cultural interactions among the population of the territories of the North Caucasus.

\section{Methods and material}

In April-May 2019, a sociological survey was carried out in Stavropol Krai, Karachay-Cherkessia, and Ingushetia by an individual survey method. The opinion of a group of respondents living outside Stavropol Krai allows us to determine the typicality of the processes of ethnic cultural interaction of the studied territory and more fully characterize the general situation in the North Caucasus.

In the course of the preliminary theoretical analysis on the research topic, objective and subjective factors were identified that affect the content and orientation of ethnic cultural interaction in the regional community. Objective factors are:

1. the general socio-economic and political situation in the country and region;

2. the degree of tension of interethnic relations;

3. historically developed social interactions between ethnic groups;

4. state policy and legal regulation of ethnic cultural interactions;

5. migration burden on the region;

6. conditions for the implementation of cultural and leisure needs;

7. the influence of cultural institutions on the formation of interethnic and ethnic cultural relations.

Subjective factors affecting the content and orientation of ethnic cultural interaction include:

1. value orientations of carriers of ethnic culture;

2. cultural tolerance;

3. willingness to perceive the culture of another ethnic group;

4. knowledge of local community culture.
A total of 527 people-residents of the North Caucasus took part in the survey, among whom 407 people representatives of Stavropol Krai and 120 people representatives of Karachay-Cherkessia and Ingushetia, respectively.

According to the main socio-demographic characteristics, the surveyed population is comparable to the main parameters of the general population.

\section{Results}

The resulting assessment of the effect of a factor related to the general socio-economic and political situation in the country and the region is the degree of respondents' satisfaction with life in general. Among the respondents, they are completely satisfied with how life is currently developing $-22.6 \%$, rather satisfied $-48.1 \%$, rather not satisfied $-14.2 \%$, not satisfied $-9.9 \%$, could not give a definite answer to the question $-5.2 \%$. The distribution of responses depending on the territory of the survey is presented in the following figure.

In general, it should be noted that the level of satisfaction with life has increased significantly compared to the previous 2013 survey. So, if the share of respondents who are completely and basically satisfied with life in 2013 was $34.3 \%$, then in $2019-70.7 \%$.

In the mechanism of ethnic cultural interaction, the starting point is the value orientations of interacting entities. Therefore, at the next stage of the analysis of empirical research data, we will present the results of the distribution of answers to the question "What is most important for you in life?".

Among the main, basic values, respondents single out, first of all:

- creation of a happy, wealthy family $(58.3 \%$ noted by respondents in Stavropol Krai in 2013 and 59.2\% in 2019);

- health care, maintaining a healthy lifestyle $(37.4 \%$ noted by respondents in Stavropol Krai in 2013 and $33.3 \%$ in 2019);

- the presence of a loved one, a true friend $(28.4 \%$ noted by respondents in Stavropol Krai in 2013 and $38.0 \%$ in 2019);

- professional self-realization $(27.1 \%$ noted by respondents in Stavropol Krai in 2013 and 25.4\% in 2019);

- honor and dignity of a person $(22.2 \%$ noted by respondents in Stavropol Krai in 2013 and 25.8\% in 2019).

The following values moved to the group of more significant values compared to the previous period:

- to love the Motherland and work for the benefit of its prosperity $(9.9 \%$ of respondents in Stavropol Krai in 2013 and $15.5 \%$ in 2019);

- to create their own business, a company (13.9\% of respondents in Stavropol Krai in 2013 and 19.2\% in 2019);

- to work in a labor collective, creating material and spiritual values together $(13.7 \%$ noted by respondents in Stavropol Krai in 2013 and $15.0 \%$ in 2019); 
- to take care of the welfare of people, protect nature (9.9\% noted by respondents in Stavropol Krai in 2013 and $13.6 \%$ in 2019);

- independent solution of problems $(9.5 \%$ noted by respondents in Stavropol Krai in 2013 and 14.6\% in 2019);

- to deal actively with manifestations of deviant behavior of people in society $(6.9 \%$ noted by respondents in Stavropol Krai in 2003 and 12.7\% in 2009);

- to live as you wish, get thrills $(8.3 \%$ of respondents in Stavropol Krai in 2013 and 12.2\% in 2019);

- an active participation in public life $(5.6 \%$ of respondents in Stavropol Krai in 2013 and 7.5\% in 2019).

- to achieve a high position in society $(6.1 \%$ noted by respondents in Stavropol Krai in 2013 and 13.6\% in 2019);

In the group of less significant values, compared with the previous period, the following have moved:

- to live like everyone else, be guided by personal interests $(14.1 \%$ noted by respondents in Stavropol Krai in 2013 and $12.2 \%$ in 2019);

- the ability to earn money, increase capital $(24.0 \%$ noted by respondents in Stavropol Krai in 2013 and $17.8 \%$ in 2019).

The following table 1 shows the distribution of attitudes towards values according to a 2013 and 2019 survey.

Table 1. Distribution of answers to the question about the value orientations of the respondent, \%

\begin{tabular}{|c|c|c|c|c|}
\hline № & $\begin{array}{l}\text { Name of the } \\
\text { value }\end{array}$ & $\begin{array}{l}\text { Stavropol } \\
\text { krai } 2013\end{array}$ & $\begin{array}{l}\text { Stavropol } \\
\text { krai } 2019\end{array}$ & $\begin{array}{l}\text { Other } \\
\text { republics } \\
2019 \\
\end{array}$ \\
\hline 1. & $\begin{array}{l}\text { To create a happy, } \\
\text { wealthy family }\end{array}$ & 58,3 & 59,2 & 63,4 \\
\hline 2. & $\begin{array}{l}\text { To have a loved } \\
\text { one, a true friend }\end{array}$ & 28,4 & 38,0 & 36,6 \\
\hline 3. & $\begin{array}{l}\text { To cherish your } \\
\text { honor and dignity }\end{array}$ & 22,2 & 25,8 & 36,6 \\
\hline 4. & $\begin{array}{l}\text { To love the } \\
\text { Motherland and } \\
\text { work for its good } \\
\text { and prosperity }\end{array}$ & 9,9 & 15,5 & 22,0 \\
\hline 5. & $\begin{array}{l}\text { To realize yourself } \\
\text { professionally in } \\
\text { the most full way, } \\
\text { have an } \\
\text { interesting, } \\
\text { creative work }\end{array}$ & 27,1 & 25,4 & 34,1 \\
\hline 6. & $\begin{array}{l}\text { To learn how to } \\
\text { make money and } \\
\text { increase your } \\
\text { capital }\end{array}$ & 24,0 & 17,8 & 22,0 \\
\hline 7 & $\begin{array}{l}\text { To create your } \\
\text { own business, } \\
\text { company, succeed } \\
\text { in business }\end{array}$ & 13,9 & 19,2 & 17,1 \\
\hline 8. & $\begin{array}{l}\text { To work in a labor } \\
\text { collective, } \\
\text { together creating } \\
\text { material and } \\
\text { spiritual values }\end{array}$ & 13,7 & 15,0 & 12,2 \\
\hline 9. & $\begin{array}{l}\text { To take care of the } \\
\text { welfare of people, }\end{array}$ & 9,9 & 13,6 & 17,1 \\
\hline
\end{tabular}

\begin{tabular}{|c|c|c|c|c|}
\hline & $\begin{array}{l}\text { protect and protect } \\
\text { nature }\end{array}$ & & & \\
\hline 10. & $\begin{array}{l}\text { To take care of } \\
\text { your health, lead a } \\
\text { healthy lifestyle }\end{array}$ & 37,4 & 33,3 & 31,7 \\
\hline 11. & $\begin{array}{l}\text { To achieve a high } \\
\text { position in society, } \\
\text { fame }\end{array}$ & 6,1 & 13,6 & 11,0 \\
\hline 12. & $\begin{array}{l}\text { To live like } \\
\text { everyone else, do } \\
\text { your own thing } \\
\text { and be guided } \\
\text { mainly r by } \\
\text { personal interests }\end{array}$ & 14,1 & 12,2 & 6,1 \\
\hline 13. & $\begin{array}{l}\text { To live as you } \\
\text { wish, have fun } \\
\text { and thrill }\end{array}$ & 8,3 & 12,2 & 14,6 \\
\hline 14. & $\begin{array}{l}\text { To deal with } \\
\text { negative } \\
\text { manifestations in } \\
\text { human behavior }\end{array}$ & 6,8 & 12,7 & 11,0 \\
\hline 15. & $\begin{array}{l}\text { I do not consider } \\
\text { anything } \\
\text { important in life }\end{array}$ & 0,9 & 4,7 & 2,4 \\
\hline 16. & $\begin{array}{l}\text { Active } \\
\text { participation in } \\
\text { public life }\end{array}$ & 5,6 & 7,5 & 6,1 \\
\hline 17. & $\begin{array}{lr}\begin{array}{l}\text { To solve } \\
\text { problems }\end{array} & \text { your } \\
\text { yourself } & \\
\end{array}$ & 9,5 & 14,6 & 19,5 \\
\hline
\end{tabular}

The next factor influencing the content and orientation of ethnic cultural interactions is the state of interethnic relations in the locality of the respondents. In general, the state of interethnic relations in the city (village) where the survey was conducted is rated as stable by half of the respondents (49.7\%) in 2013 and $57.9 \%$ in $2019.32 .0 \%$ of respondents in 2013 and $17.4 \%$ in 2019 said that there was interethnic tension, there was strong interethnic tension, according to only $3.1 \%$ of respondents in 2013 and $5.7 \%$ - in 2019, another 15, 2\% of respondents refrained from a specific assessment of the situation in 2013 and $19.0 \%$ in 2019.

Respondents noted how ethnic tension manifests itself in the following facts from the daily lives of citizens:

$>$ manifestation in some people of prejudices that impede the establishment of friendly relations between people of different nationalities $-35.4 \%$ in 2013 and $22.8 \%$ in 2019 ;

$>$ hooligan actions and other disturbances of public order on a national basis $-34.5 \%$ in 2013 and $24.9 \%$ in 2019;

$>$ hostile attitude towards residents of other republics of the former Union engaged in business, trade in the city $-23.4 \%$ in 2013 and $22 \%$ in 2019 ;

$>$ appointment to senior or prestigious positions on a national basis - 17.5\% in 2013 and $13.1 \%$ in 2019;

$>$ hiring (studying) on a national basis $15.9 \%$ in 2013 and $13.4 \%$ in 2019;

$>$ crowding out of leadership or prestigious posts on a national basis $-8.5 \%$ in 2013 and $6.3 \%$ in 2019;

$>$ the distribution of wealth depending on the nationality of people $-7.4 \%$ in 2013 and $6.2 \%$ in 2019; 
hostile attitude towards people of other nationalities at your enterprise, institution, company, etc. $-6.1 \%$ in 2013 and $3.5 \%$ in 2019 ;

$>$ nationalist propaganda $-5.4 \%$ in 2013 and $2.3 \%$ in 2019.

In principle, $13.1 \%$ of the respondents in 2013 and $6.7 \%$ in $2019,57.9 \%$ of the respondents in 2013 and $54.8 \%$ in 2019 consider the use of force as unacceptable in solution of interethnic problems and exclusively forceful decisions were in favor of $8.3 \%$ of respondents in 2013 and $27.6 \%$ in 2019 . At the same time every fifth respondent in 2013 was not able to concretize their position on this issue, and in 2019 the option "I find it difficult to answer" was noted by $11.0 \%$ of the respondents.

In the opinion of almost a third of respondents, both in Stavropol Krai and in the national republics of the North Caucasus, strict administrative measures will be most effective in solving ethnic problems. In addition, $22.2 \%$ of respondents in Stavropol Krai and $28.4 \%$ in Karachay-Cherkessia consider the creation of interethnic councils to be an effective impact on the situation. Such a measure as the creation of national-cultural autonomies and centers of national culture was also estimated approximately. A much smaller role is given to the development of a network of cultural institutions of a multidisciplinary nature.

The next important factor is government policy and the legal regulation of ethnic cultural interactions. How the implementation of the established provisions at the level of territorial entities is proceeding, let us consider the example of assessments of the activities of local authorities by respondents of different nationalities. The distribution of answers to the question: "To what extent, in your opinion, the interests of your national group are taken into account in the work of local authorities?" shows that for representatives of non-Russian nationalities, according to their own estimates, this problem is somewhat more acute than for Russians, especially in areas where the share of non-Russians is above the average along the edge.

An analysis of the distribution of answers to the question about the number of representatives of different nationalities in the close circle of respondents of nonRussian nationalities living in the national republics of the North Caucasus shows that $70.0 \%$ of such contacts have increased over the past 10 years, and only $13.8 \%$ of respondents their number has decreased.

Respondents also note that among their close friends and acquaintances, there are practically no people conflicting on a national basis $(75.9 \%$ of respondents noted in 2013 and $72.2 \%$ in 2019) - these are three quarters of the respondents. Another 52.8\% of respondents in 2013 and $46.2 \%$ in 2019 believe that there is no ethnic tension at the level of relationships between ordinary people. The share of those survey participants in Stavropol Krai who noted that conflicts on an interethnic basis is artificially created and inflamed by politicians and those who benefit from it has significantly decreased. If in 2013 there were $62.3 \%$ of the numbers of respondents, then in $2019-42.8 \%$.
According to the results of a survey in 2019 in Stavropol Krai, the share of respondents increased who believe that if we consider the culture of life in a broad sense, it does not have a national color $(39.1 \%$ of respondents noted in 2013 and $45.5 \%$ in 2019. Household is traditional for their nationality - this option was noted by $35.1 \%$ of respondents in 2013 and $28.7 \%$ in 2019 . $12.8 \%$ of respondents in 2013 and $13.4 \%$ said about using the positive experience of other nationalities in 2019.

Among the family traditions, that are supported in the families of Stavropol Krai, is national cuisine (33.3\% of the respondents noted in 2013 and $39.9 \%$ - in 2019); $30.1 \%$ of respondents in 2013 and $25.9 \%$ - in 2019 indicated that they gathered and sang folk songs. In recent years, the proportion of those who name children in honor of their ancestors has increased - if in 2013 this is $28.3 \%$ of the numbers of respondents, then in $2019-$ $41.3 \%$.

\section{Discussion and conclusions}

Based on the results of the study, the following conclusions were made:

1. An increase in the specific gravity of non-titular nationalities for Stavropol Krai, on the one hand, causes greater interpenetration of cultures, their mutual enrichment, on the other hand, an increase in the intensity of interaction between different national groups leads to the need for closer attention to the development of balanced national policies in the region.

2. According to respondents, an increase in information about the history and culture of peoples living in the territory of the region will become a stabilizing factor in interethnic relations.

3. The research materials confirm the persistence of the situation when at the level of interpersonal relationships (in the family, immediate environment, production teams) ethnic tension is expressed to a much lesser extent than at the level of social relations between ethnic groups living in Stavropol Krai and the North Caucasus as a whole. The complexity of interethnic interactions is to some extent determined by the mobilization of the ethnic factor by a number of political forces.

4. The majority of respondents are unanimous in their opinion that the customs and traditions of the peoples living in Stavropol Krai are a universal cultural heritage.

5. Respondents of both the titular nationality for Stavropol Krai (Russians) and representatives of other nationalities believe that they have the same opportunities to preserve the national culture.

6. Institutions that harmonize, as a whole, interethnic and including ethnic cultural relations are cultural institutions and national-cultural centres, the functioning and development of which require state support. 


\section{Recommendations and research prospects}

The information obtained during the study is important for improving interethnic relations in the North Caucasus and for developing a balanced socio-economic and cultural policy. The research strategy can be complemented by benchmarking with other regions and national groups.

Monitoring studies of issues of interethnic interactions in the region will help understanding the vectors of the development of interethnic relations for the long term; provide a balance of interests of different nationalities, which is important for the sustainable development of the North Caucasus.

\section{References}

1. O. McDoom, Journal of Ethnic and Migration Studies, 45(9), 1532-1552 (2019)

2. A. Bashta, V. Shostka, M. Zelentsova, IOP Conference Series: Earth and Environmental Science, 272(3), 032197 (2019)

3. L. Leszczensky, P. Jugert, S. Pink, Journal of Social Issues, 75(2), 460-485 (2019)

4. D. Grigoryev, S. Fiske, A. Batkhina, Frontiers in Psychology, 10(JULY), 1643 (2019)

5. S. Ryzhova, Sotsiologicheskie Issledovaniya, 2019January (2), 49-58 (2019)

6. T. Seregina, A. Masalimova, M. Usak, E. Dorozhkin,

A. Galushkin, XLinguae, 12(2), 186-194 (2019)

7. B. Formoso, Ethnologie Francaise, 173(1), 195-206 (2019)
8. B. Wickström, J. Landa, Journal of Bioeconomics, 20(3), 263-286 (2018)

9. M. Barwiński, European Spatial Research and Policy, 26(1), 149-173 (2019)

10. Y. Zografova, Qualitative Sociology Review, 15(2), 26-43 (2019)

11. N. Otpenov, K. Smagulov, A. Al'muhametov, A. Akimhanov, N. Anarbaiev, European Journal of Science and Theology, 15(2), 179-189 (2019)

12. K. Yensenov, G. Karasayev, S. Dyusen, B. Naimanbayev, M. Islamov, Analele Universitatii din Craiova - Seria Istorie, 35(1), 79-92 (2019)

13. E. Brodovskaya, A. Dombrovskaya, I. Batanina, Communications in Computer and Information Science, 947, 363-373 (2019)

14. J. Irgengioro, East Asia, 35(4), 317-346 (2018)

15. A. Grinëv, Sexuality and Culture, 22(4), 1340-1360 (2018)

16. S. Gherghina, N. Silagadze, Nationalism and Ethnic Politics, 24(4), 389-410 (2018)

17. J. Geerlings, J. Thijs, M. Verkuyten, Journal of School Psychology (2019)

18. R. Toksonalieva, G. Musurmanova, A. Toksonalieva, Z. Koshmatova, M. Yuldashev, Studies in Computational Intelligence, 826, 789-798 (2019)

19. N. Astashova, S. Bondyreva, O. Zhuk, Obrazovanie i Nauka, 21(3), 29-49 (2019)

20. A. Koriakina, T. Tretyakova, V. Ignatiev, S. Olesova, Espacios, 40(9) (2019)

21. R. Vervaet, M. Van Houtte, P. Stevens, Teaching and Teacher Education, 76, 68-77 (2018) 